tigators found this explanation "unacceptable" because principle investigators are responsible "for personally conducting and supervising the clinical investigations." Katz was working on two clinical trials of unnamed investigational hypertension drugs. Faxon was comparing the effectiveness of an unnamed drug to aspirin as a means of preventing complications from post-acute coronary syndrome. Both have now been instructed to limit the size and number of clinical studies they supervise for the next three years and attend educational programs. Faxon, who is now chief of Cardiology at the University of Chicago, was also last year's president of the prestigious American Heart Association.

The FDA inspects around 1,100 research programs annually. So far this year, it has restricted the work of Katz and Faxon, and disqualified three researchers-a negligible number which suggests a strong record of correct procedure. But in a recent study in the New England Journal of Medicine, academic institutions were accused of "routinely" conducting industry-sponsored research that does not meet guidelines for study design and access to data. And a study in The Lancet reported that $23 \%$ of the scientific advisors to British drug-regulatory agencies have financial links to the pharmaceutical industry.

Tinker Ready, Boston

\section{FP6 brings bigger funds and some confusion}

November 11 saw the long-awaited launch of Europe's Sixth Framework Program for Research (FP6), which will determine European Union research spending over the next five years. Although FP6 funds all scientific research, genomics and 'biotechnology for health' are priority themes, and these areas have been awarded a record budget of 2.25 billion Euros ( $\$ 2.27$ billion).

The launch followed months of debate and discussion between politicians and researchers on how

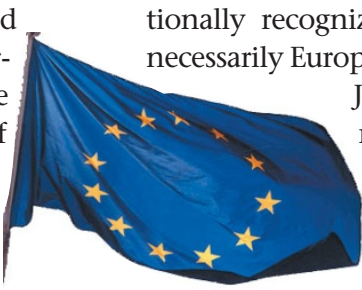

researchers in Europe and the US, and FP6 officials are keen to promote collaborations outside Europe. The measure of "excellence" in integrated projects and networks of excellence will be evaluated by internationally recognized experts who are not necessarily Europeans.

Johan Auwerx, a mouse geneticist involved in a similar pilot project, sees advantages to the new system. Studies of the mouse genome were in funds would be administered. Final details remained undisclosed until the last minute and some of the biggest names in European research were left wondering what they might be eligible to apply for. "I'm still slightly confused," says Leena Peltonen, leader of the Molecular Neurobiology Group at the University of Helsinki and founding chair of the Department of Human Genetics at the University of California Los Angeles.

Part of the confusion lies in the decision to create two new "instruments" to correct perceived flaws of FP5, namely that funds were often spread too thinly over too many different topics, and that collaborations fizzled out at the end of each research project. Thus, the first new instrument, "integrated projects", will focus major funds on a smaller number of research programs. The second is "networks of excellence", aimed at integrating network partners to establish long-lived "virtual" centers of excellence. But it is still unclear what "networks of excellence" will actually fund. Will they cover expensive lab equipment? Will particular research topics be supported?

Other European researchers struggling to understand the system might take heart from Peltonen's confusion, particularly as she is involved in a pilot project for the new system. Peltonen is leading a project to identify common disease genes in 600,000 European twin pairs. The effort comprises
"Although Europe has key players in this field, there was a shortage of structured initiatives to tackle mouse functional gefunds to renovate university labs. ing," the report charges. being made with the present levels." view of science and research. nomics in a systematic way," says Auwerx, of France's Institut de Génétique et de Biologie Moléculaire et Cellulaire.

But he joins the chorus of dissatisfaction at the mountain of EU paperwork facing grant applicants. "There is too much bureaucracy," complains Antoni Trilla of the University of Barcelona, coordinator of the EU-funded European and Developing Countries Clinical Trials Partnership (EDCTP). Trilla will be applying for 200 million Euros (\$202 million) of "basic seed money" to establish the EDCTP, an AfricanEuropean partnership to coordinate research into poverty-related diseases.

The first calls for proposals to FP6 are due in December. See http://europa.eu.int/ comm/research/fp6/index_en.html

Bea Perks, London

\title{
British government spending does not add up
}

\section{The government office that funds biomedical research in Britain has been accused of mis-} leading scientists over the true magnitude of a recently announced funding increase. In a report published on 6 November, the parliamentary committee on science and technology attacked the government Office of Science and Technology (OST) for making "misleading" statements following the comprehensive spending review earlier this year.

In July, the OST-which channels government money to British funding agencies including the Medical Research Council and the Biotechnology and Biological Sciences Research Council-announced a $£ 890$-million ( $\$ 1.4$ billion) increase in the science budget over the next three years. The announcement included an extra $£ 400$ million ( $\$ 635$ million) for research grants, $£ 100$ million ( $\$ 159$ million) to raise salaries for young researchers and fresh

But the committee report now says that the overall increase in the science budget as a result of the spending review is more accurately represented as $£ 660$ million ( $\$ 1.05$ billion). The remaining $£ 230$ million ( $\$ 365$ million) was already planned under the previous spending review in 2000. "The way in which the spending review... presents increases to science spending is misleading and leaves the government open to accusations of double-count-

A spokesperson for the OST denied there was any deliberate deception. "There is no question of double accounting," she says. "We simply compared the planned expenditure in 2005-06 with the expenditure now. It was always made clear that comparisons were

Committee chair lan Gibson says the OST and the government have lessons to learn. "There is much more work to be done to ensure greater openness and accountability in government's policy-making on science and technology," Gibson says. The report also calls on the OST to be more transparent with its performance targets and says it welcomes the recent decision by the government to agree to publish the results of a new crosscutting re-

DAVID ADAM, LONDON 